An Introduction to Thyristors and Their Applications 
To my wife

Lakshmi 


\section{An Introduction to Thyristors}

and

Their Applications

M. Ramamoorty

Professor of Electrical Engineering Indian Institute of Technology

Kanpur 
All rights reserved. No part of this publication may be reproduced or transmitted, in any form or by any means, without permission.

First published in India 1977

by Affiliated East-West Press Private Limited

Published in the United Kingdom 1978 by

THE MACMILLAN PRESS LIMITED

London and Basingstoke

Associated companies in Delhi Dublin

Hong Kong Johannesburg Lagos Melbourne

New York Singapore and Tokyo

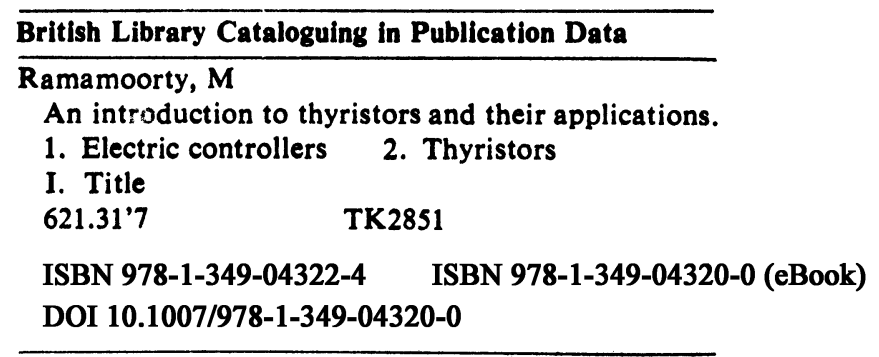

This book is sold subject to the standard conditions of the Net Book Agreement.

The paperback edition of this book is sold subject to the condition that it shall not, by way of trade or otherwise, be lent, resold, hired out, or otherwise circulated without the publisher's prior consent in any form of binding or cover other than that in which it is published and without a similar condition including this condition being imposed on the subsequent purchaser. 


\section{Contents}

Preface $\quad$ xi

\section{Solid-State Power Control}

1.1 Introduction 1

1.2 Historical Development 2

1.3 Nature, Characteristics, and Applications 2

1.4 Comparison of Thyrations with Power Transistors 3

1.5 Thyristors-Symbolic Representation 4

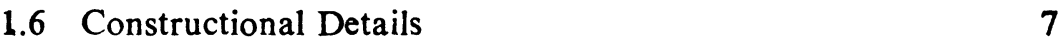

$\begin{array}{ll}\text { References } & 8\end{array}$

2 Thyristors

2.1 SCR Characteristics 9

2.2 Principle of Operation 9

2.3 Transistor Analogy 10

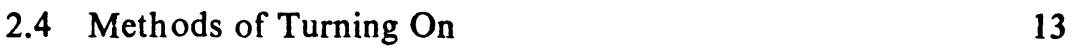

$\begin{array}{lll}2.5 & \text { Turn-Off Mechanism } & 14\end{array}$

2.6 Device Specifications, Ratings, and Nomenclature 15

$\begin{array}{lll}2.7 & \text { Improvement of Device Characteristics } & 18\end{array}$

$\begin{array}{ll}2.8 \text { Gate Characteristics } & 20\end{array}$

2.8.1 Example $\quad 21$

$\begin{array}{ll}2.8 .2 \text { Gate circuit parameters } & 22\end{array}$

2.8.3 Measurement of device parameters 24

2.8.4 Example 25

2.8.5 Circuits for gate triggering 25

2.9 Internal Power Dissipation and Temperature Rise 28

2.9.1 Example $\quad 31$

References $\quad 32$

3 Multiple Connections of SCRs

3.1 Series-Parallel Operation of SCRs 33

$\begin{array}{lll}3.2 & \text { Series Operation } & 34\end{array}$

3.2.1 Triggering of series-connected SCRs 36

$\begin{array}{lll}3.3 & \text { Parallel Operation } & 38\end{array}$

3.3.1 Triggering of parallel-connected SCRs 39 
3.4 String Efficiency 40

3.5 Example $\quad 41$

References $\quad 42$

4 Power and Switching Devices

4.1 Thyristors 43

4.2 Low-Power Devices 43

4.2.1 Exarnple $\quad 46$

4.3 Unijunction Transistor (UJT) 47

4.3.1 Relaxation oscillator using a UJT 48

4.3.2 Frequency stability $\quad 50$

4.3.3 Example 50

4.4 Triac 51

4.4.1 Triggering mode $\quad 52$

4.4.2 Phase control using a triac 53

4.5 Special Devices 54

References $\quad 54$

5 Applications

5.1 Power Control 55

5.1.1 Example 57

5.2 Static Circuit Breaker $\quad 58$

5.2.1 Example $\quad 59$

5.3 Overvoltage Protection $\quad 59$

5.4 Zero Voltage Switch 60

5.5 Integral-Cycle Triggering 61

5.6 Time Delay Circuit 62

5.7 Soft Start Circuit $\quad 62$

5.8 Logic and Digital Circuits 63

5.9 Pulse Circuits 64

References $\quad 65$

6 AC Power Control

6.1 Phase Control 66

6.2 Full-Wave Control Circuit 68

6.2.1 Analysis of a bridge circuit $\quad 70$

6.2.2 Effect of source inductance $\quad 73$

6.2.3 Operation as a two-quadrant converter $\quad 74$

6.2.4 Performance with a free-wheeling diode $\quad 76$

$\begin{array}{lll}\text { 6.2.5 Example } & 77\end{array}$

6.3 Half-Controlled Bridge Circuits 78

6.4 Dual Converters 83

6.4.1 Example $\quad 84$ 
6.5 Phase-Control Circuit 85

6.5.1 Modified ramp control 88

6.5.2 Control by a voltage-controlled oscillator (VCO)

6.5.3 Derating of SCRs in phase control 92

6.5.4 Example $\quad 92$

6.6 Application to Speed Control of Motors 92

6.6.1 Phase control of three-phase induction motors

6.7 Regulated DC Power Supplies 97

6.7.1 Example 98

6.8 DC Motor Control 99

6.8.1 Stability in DC motor drives 102

$\begin{array}{ll}\text { 6.8.2 Example } & 103\end{array}$

6.8.3 Other control circuits for DC drives 103

6.8.4 Simple speed control circuit for DC motors 105

6.8.5 Improved speed control scheme for DC motors

107

References

111

\section{Line-Commutated Converters and Inverters}

7.1 Line-Commutated Circuits

7.1.1 In put-out put characteristics of bridge circuits

7.1.2 Example

112

120

7.2 Effect of Source Impedance 121

$\begin{array}{lll}\text { 7.2.1 Example } & 123\end{array}$

$\begin{array}{ll}\text { 7.2.2 Effect of load inductance } & 124\end{array}$

7.2.3 Discontinuous-current operation 125

$\begin{array}{lll}7.2 .4 & \text { Transient operation } & 128\end{array}$

$\begin{array}{lll}7.2 .5 & \text { Example } & 128\end{array}$

7.2.6 Effect of overlap angle 129

7.2.7 Example 131

7.2.8 Interphase reactor connection 131

7.2.9 Commutation with a capacitive source impedance 133

7.3 Inverter Operation 134

$\begin{array}{lll}\text { 7.3.1 Example } & 140\end{array}$

7.4 Slip Power Recovery Scheme for Speed Control of Induction Motors

7.4.1 Through-pass inverter 142

7.4.2 DC transmission 143

$\begin{array}{lll}\text { 7.4.3 Example } & 148\end{array}$ 
7.5 Frequency Changers

7.5.1 Example

7.5.2 High-frequency conversion

7.6 Cycloconverters

7.6.1 Mathematical analysis

7.6.2 Bridge configuration

7.6.3 Control circuit 162

7.6.4 Improved cycloconverter circuits $\quad 165$

7.6.5 Harmonic analysis 168

7.6.6 Circulating-current scheme 169

7.6.7 Input characteristics of a cycloconverter $\quad 170$

7.6.8 Cycloconverter drives 171

7.7 Example

References

\section{Parallel-Series Inverters}

8.1 Forced-Commutated Inverters 175

8.2 Classification of Circuits for Forced Commutation 176

$\begin{array}{lll}8.3 \text { Example } & 179\end{array}$

8.4 Parallel Inverter 180

8.4.1 General characteristics of parallel inverter 182

8.4.2 Design of commutating components 184

8.4.3 Output voltage and waveform control 187

$\begin{array}{ll}\text { 8.4.4 Example } & 189\end{array}$

8.5 Poly phase Inverter 191

8.5.1 Example 193

8.6 Series Inverter 195

$\begin{array}{ll}\text { 8.6.1 Circuit operation } & 197\end{array}$

8.6.2 Design considerations 198

8.6.3 Improved series inverters 198

8.6.4 Three-phase series inverter 201

8.6.5 High-frequency series inverter 201

8.6.6 Example 203

8.7 Self-Commutated Inverters 204

8.7.1 Inverter connections 204

8.7.2 Mathematical analysis 207

8.7.3 Example 209

References 209

\section{Bridge Inverters}

9.1 Principles of Operation 211

9.1.1 Commutation circuits 212

9.1.2 Example 216

9.2 Operation of a Single-Phase Bridge Inverter 219

9.2.1 Example 
9.2.2 Auxiliary-commutated single-phase bridge inverter

9.2.3 Inverter circuit with complementary commutation

9.3 Three-Phase Bridge Inverters

9.3.1 Commutation circuits 228

9.3.2 Example

9.3.3 Auxiliary-commutated inverters 232

9.3.4 Example 236

9.4 Current-Source Inverter 238

9.4.1 High-frequency inverter with forced commutation

239

9.4.2 Example

9.5 Inverter Output Voltage and Waveform Control 242

9.6 Inverter Control Circuits 244

9.6.1 Six-state sequential circuit 244

9.6.2 Decoding circuit 247

9.7 Inverter Applications 248

9.8 Example 252

References 254

10 Choppers

10.1 On-Off Control 256

10.1.1 Example 259

10.2 Rotor On-Off Control 259

10.2.1 Example 261

10.3 Control of DC Motors 261

10.3.1 Example 263

10.4 Chopper Circuits 263

10.4.1 Circuit performance 264

10.4.2 Design considerations 266

10.4.3 Example 267

10.5 Improved Chopper Circuits 267

10.6 Step-Up Chopper 269

10.7 Multiphase Chopper Circuits 269

10.8 Two-Quadrant Chopper 271

10.9 AC Choppers 272

References $\quad 274$

11 Reliability

11.1 Thyristor Protection Circuits 276

11.2 Gate-Control Circuit 276

11.3 Overvoltage and Overcurrent Protection 277 
X CONTENTS

11.3.1 Overcurrent protection 278

$\begin{array}{lll}11.3 .2 & \text { Example } & 279\end{array}$

11.3.3 Intermittent current waveforms 280

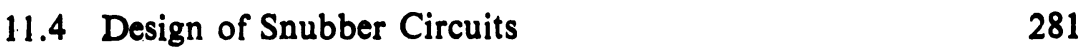

11.4.1 Example $\quad 282$

11.5 SCR Mounting 283

$\begin{array}{lll}11.6 & \text { SCR Reliability } & 284\end{array}$

References $\quad 284$

General References $\quad 285$

$\begin{array}{ll}\text { Problems } & 286\end{array}$

$\begin{array}{lll}\text { Appendix Selection of SCRs } & 301\end{array}$

$\begin{array}{ll}\text { Index } & 307\end{array}$ 


\section{Preface}

The rapid development of semiconductor technology has revolutionised the art of power modulation. "Thyristor" has become a byword for control in many industrial applications and the subject of several books. Some of these books emphasise its physics and characteristics, and some discuss one or the other of its applications in detail. Few qualify as texts for the undergraduate who needs not the details, which are available in handbooks and journals and/or in the teacher's lectures, but rather the basics.

In an attempt to fill in the lacuna, this text concentrates on the fundamentals of the operation of the thyristor and on its applications. No effort is made to go into the details of system design as a whole. The control circuits described for various applications using thyristors are not meant to be commercially feasible, but provide the basic understanding necessary for synthesising more sophisticated controllers.

The book, as its title indicates, serves as an introductory course on the thyristor and its applications to power control. It is, in fact, based on the lectures of such a course which the author has offered several times over the past few years. The volume is intended primarily for those undergraduates specialising in power control and industrial drives. Such readers have usually had a basic grounding in electronics, electric circuits and machines, and control theory.

The entire content can be covered in a two-semester course. The physics and characteristics of the thyristor, the methods of turning on and off, protection, general applications, phase control, and some fundamental aspects of line-commutated converters and inverters may be allotted to the first semester. The second semester may be devoted to Chapters 7 to 10 which focus attention on industrial controls involving all classes of forcedcommutated circuits, and include a brief treatment of some important types of drives and their characteristics and the performance of controllers.

The illustrative problems at the end of the study are intended more to help the student gain an insight into the applications than to test his mathematical skill. A large number of examples are worked out in each chapter to facilitate a grasp of the subject. The list of important references, which identifies the source of material covered, proves useful when additional data is required. 